\title{
Migratory Rolandic Encephalopathy Caused by the Mitochondrial ND3 Mutation
}

\section{Author(s):}

Kunqian Ji, MD ${ }^{1}$; Hong Ren, $\mathrm{MD}^{1}$; Xiuhe Zhao, $\mathrm{MD}^{1}$; Chuanzhu Yan, $\mathrm{MD}, \mathrm{PhD}^{1,2}$ on behalf of Department of Neurology, Qilu Hospital, Shandong University

\section{Corresponding Author:}

Chuanzhu Yan

czyan@sdu.edu.cn

Neurology® Published Ahead of Print articles have been peer reviewed and accepted

for publication. This manuscript will be published in its final form after copyediting,

page composition, and review of proofs. Errors that could affect the content may be corrected during these processes. 
Affiliation Information for All Authors: 1.Department of Neurology, Qilu Hospital, Shandong University, Jinan, Shandong, 250012 ,China; 2.Mitochondrial Medicine Laboratory, Qilu Hospital (Qingdao), Shandong University, Qingdao, Shandong, 266035, China

\section{Contributions:}

Kunqian Ji: Drafting/revision of the manuscript for content, including medical writing for content

Hong Ren: Analysis or interpretation of data

Xiuhe Zhao: Major role in the acquisition of data

Chuanzhu Yan: Study concept or design

Number of characters in title: 74

Abstract Word count:

Word count of main text: 100

References: 1

Figures: 1

Tables: 0

Neuroimage Legend Count: 46

Search Terms: [ 60 ] All Epilepsy/Seizures, [96 ] Mitochondrial disorders, [ 120 ] MRI

Study Funding: This study was supported by the the National Natural Science Foundation of China (No.82171394), the policy supported projects of collaborative innovation and achievement transformation in universities and research institutes of Jinan (2019GXRC050), the Taishan Scholars Program of Shandong Province and the Qingdao Key Health Discipline Development Fund.

Disclosures: The authors report no disclosures relevant to the manuscript.

An 18-year-old woman was admitted to the hospital for focal seizures. Serial MRI studies showed migratory Rolandic lesions (figure A-D), and the EEG showed sharp waves when the lesion appeared. The initial differential diagnosis included cerebral venous thrombosis, MOGAD and metabolic disorders. MRV, serum and CSF analyses were unrevealing. An analysis of the entire mtDNA of urine sediment by NGS showed a pathogenic m.10191T $>\mathrm{C}$ mutation in the $m t-N D 3$ gene (mutation load, 87\%). Further analysis revealed the m.10191T >C variant was heteroplasmic in blood $(24 \%)$ and oral mucosal $(86 \%)$ cells. This case illustrates that $\mathrm{m} .10191 \mathrm{~T}>\mathrm{C}$ mutation may 
present with migratory Rolandic encephalopathy ${ }^{1}$.

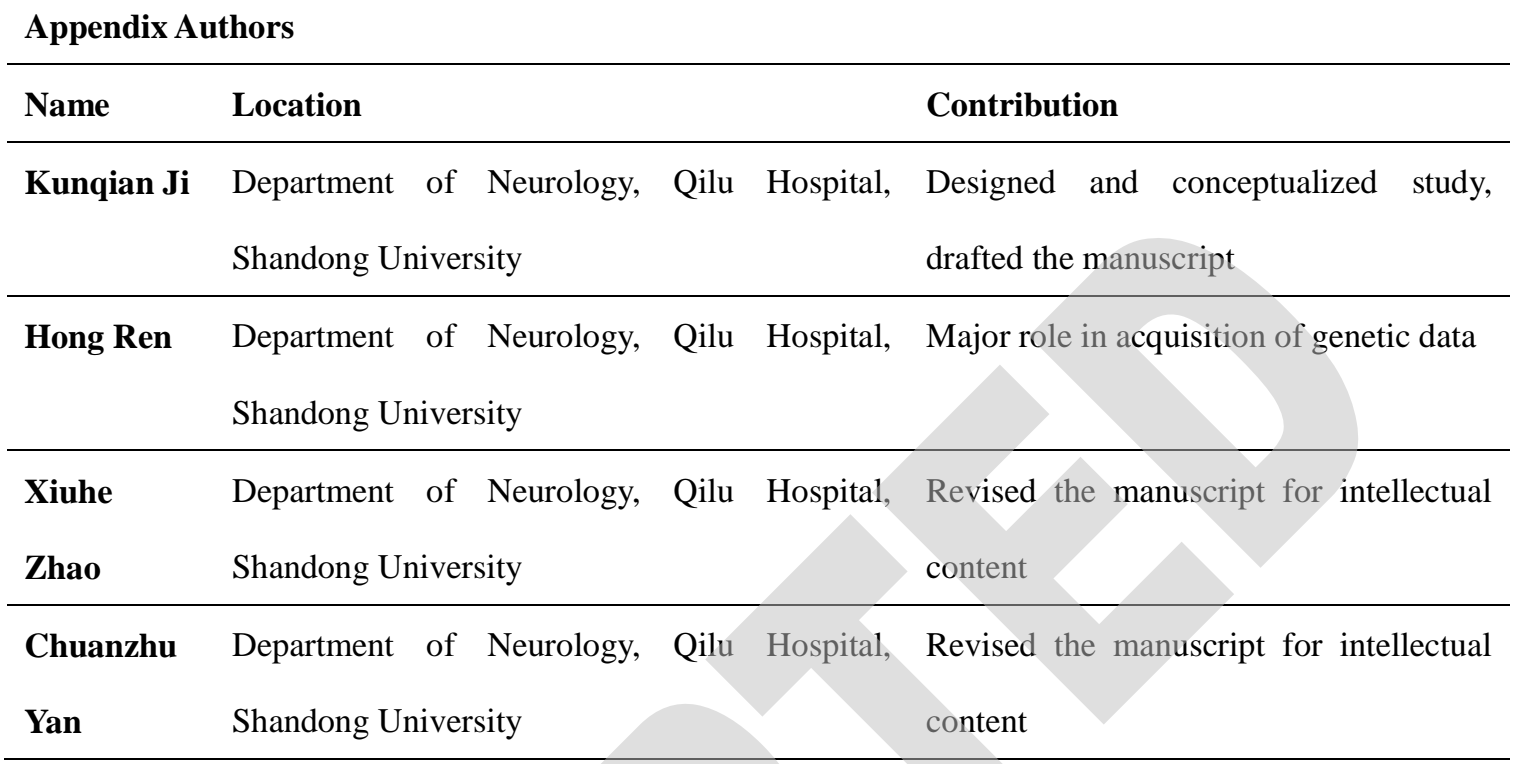

\section{References}

1. Werner KG, Morel CF, Kirton A, et al. Rolandic mitochondrial encephalomyelopathy and MT-ND3 mutations. Pediatr Neurol 2009;41:27-33. 
Figure. MRI findings of Migratory Rolandic Encephalopathy

FLAIR image of the patient at the initial neurologic examination 1 year ago (A) and the tiny lesion at the left Rolandic cortex disappeared 2 months later(B) and reappeared 9 months later (C). Then additional similar tiny lesions developed in the right Rolandic cortex later (D).
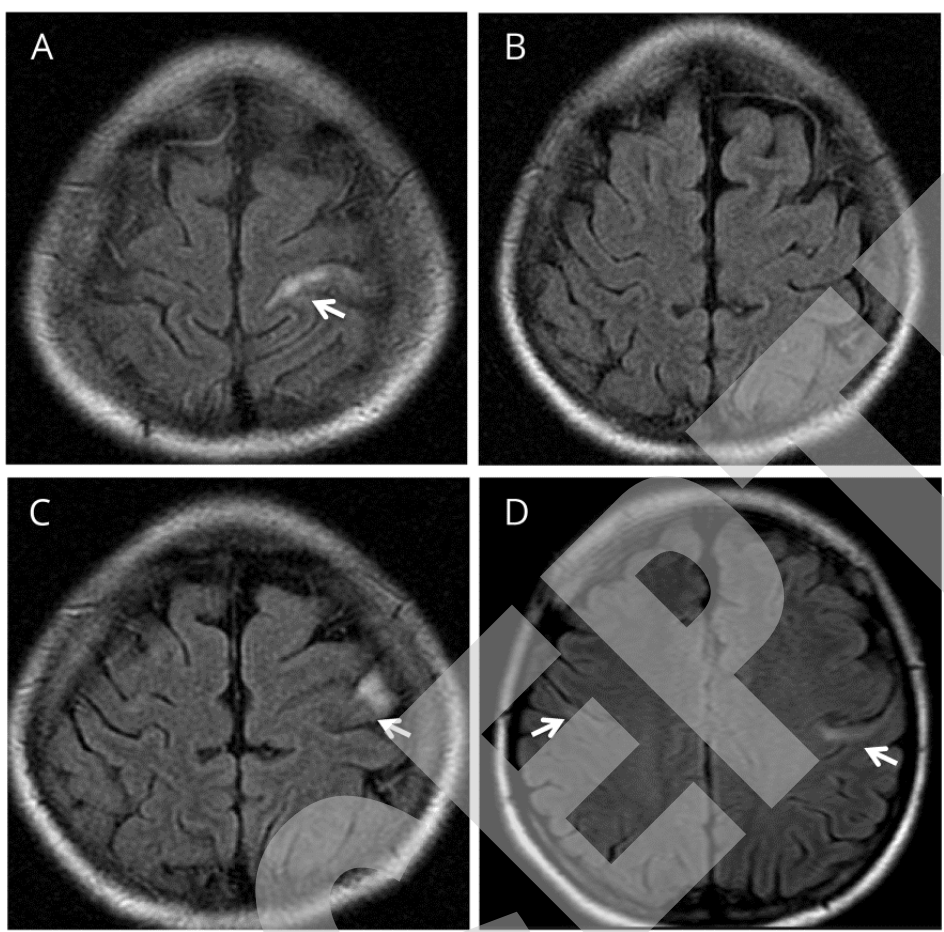


\section{Neurology}

\section{Migratory Rolandic Encephalopathy Caused by the Mitochondrial ND3 Mutation}

Kunqian Ji, Hong Ren, Xiuhe Zhao, et al.

Neurology published online October 29, 2021

DOI 10.1212/WNL.0000000000013015

This information is current as of October 29, 2021

Updated Information \&

Services

Subspecialty Collections

Permissions \& Licensing

Reprints including high resolution figures, can be found at:

http://n.neurology.org/content/early/2021/10/28/WNL.0000000000013015. citation.full

This article, along with others on similar topics, appears in the following collection(s):

All Epilepsy/Seizures

http://n.neurology.org/cgi/collection/all_epilepsy_seizures

Mitochondrial disorders

http://n.neurology.org/cgi/collection/mitochondrial_disorders

MRI

http://n.neurology.org/cgi/collection/mri

Information about reproducing this article in parts (figures,tables) or in its entirety can be found online at:

http://www.neurology.org/about/about_the_journal\#permissions

Information about ordering reprints can be found online:

http://n.neurology.org/subscribers/advertise

Neurology $\AA^{\circledR}$ is the official journal of the American Academy of Neurology. Published continuously since 1951, it is now a weekly with 48 issues per year. Copyright (C) 2021 American Academy of Neurology. All rights reserved. Print ISSN: 0028-3878. Online ISSN: 1526-632X.

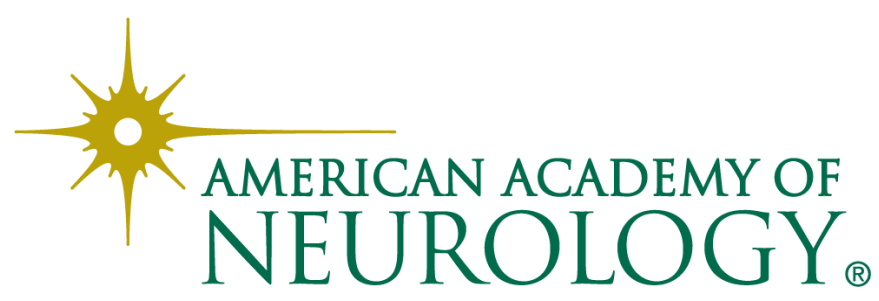

